Article

\title{
Assessment of Water Quality in Roof-Harvested Rainwater Barrels in Greater Philadelphia
}

\author{
Kerry A. Hamilton ${ }^{1, *(\mathbb{D})}$, Kerrianne Parrish ${ }^{1}$, Warish Ahmed ${ }^{2}$ and Charles N. Haas ${ }^{1}$ \\ 1 Department of Civil, Architectural, and Environmental Engineering, Drexel University, 3141 Chestnut Street, \\ Philadelphia, PA 19104, USA; kparris1@ccp.edu (K.P.); haas@drexel.edu (C.N.H.) \\ 2 Commonwealth Scientific and Industrial Research Organization, Land and Water, Ecosciences Precinct, \\ 41 Boggo Road, Dutton Park, Brisbane, QLD 4102, Australia; warish.ahmed@csiro.au \\ * Correspondence: kh495@drexel.edu; Tel.: +1-215-895-6499
}

Received: 9 November 2017; Accepted: 15 January 2018; Published: 24 January 2018

\begin{abstract}
A study of water quality parameters was conducted in 38 small-scale roof-harvested rainwater barrels (RHRB) located in urban and peri-urban Philadelphia, USA in winter (November-December) 2014 and summer (June-August 2016). Parameters included two fecal indicator bacteria (FIB) (Escherichia coli and Enterococcus spp.) measured using culture-based methods, eight potential enteric and opportunistic pathogens (Campylobacter jejuni, Acanthamoeba spp., Legionella spp., L. pneumophila, Naegleria fowleri, Pseudomonas aeruginosa, Mycobacterium avium and Mycobacterium intracellulare) measured using quantitative polymerase chain reaction (qPCR), and two metals (lead and zinc) using inductively coupled plasma mass spectrometry (ICP-MS). Fecal indicator bacteria were detected in greater than 60\% RHRB samples and concentrations (up to $>10^{3}$ per $100 \mathrm{~mL}$ ) exceeded US Food and Drug Administration (USFDA) irrigation water quality standards. Among the enteric and opportunistic pathogens tested, 57.9, 44.7, 21.1, 18.4, 5 and 3\% were PCR positive for Legionella spp., M. intracellulare, M. avium, Acanthamoeba spp., P. aeruginosa, and C. jejuni, respectively. $N$. fowleri and L. pneumophila were not detected in any sample. The concentrations of enteric and opportunistic pathogens ranged from $10^{2}$ to $10^{7}$ gene copies/L of barrel water. Lead and zinc were each observed in $88.5 \%$ of RHRB but the concentrations did not exceed US Environmental Protection Agency (USEPA) standards for irrigating produce, with the exception of one zinc observation $(2660 \mu \mathrm{g} / \mathrm{L})$. Based on these data, it appears that the risk associated with metals in RHRB is likely to be low, as these barrels are only used for gardening and non-potable purposes. However, risks due to fecal and opportunistic pathogens may be higher due to exposure to aerosols during gardening activities and produce consumed raw, and should be investigated further.
\end{abstract}

Keywords: roof-harvested rain barrel; opportunistic pathogens; enteric pathogens; fecal indicator bactera; quantitative PCR; health risks

\section{Introduction}

As urban populations grow, corresponding increases in water demand have resulted in enhanced interest in alternative and decentralized potable and non-potable water resources [1]. In addition, many urban areas struggle to manage excess stormwater flows, and are served by combined sewer overflow systems (CSOs). CSOs can introduce untreated sewage into waterbodies during rain events. In the United States, the use of roof-harvested rainwater barrels (RHRB) for non-potable usages is gaining popularity as a way to address these concerns by alleviating pressure on centralized water and wastewater systems, practicing water conservation, and decreasing potable and non-potable water demand [2]. In urban developed areas such as Philadelphia, USA, residents typically do not rely on rainwater as a primary water source, but instead use it for non-potable purposes. The city of 
Philadelphia has encouraged stormwater management at the household level by providing 55-gallon food-grade plastic barrels free of charge to residents who attended a workshop, and stated during the workshop that the barrel water should not be used for potable supply or on edible plants [3]. However, previous findings elsewhere have shown the presence of potential pathogens [4-6], metals [7], and chemicals [8-10] in roof-harvested rainwater (RHRW) tanks. Therefore, an assessment of potential contaminants and risks is warranted to guide appropriate uses of water stored in RHRB, and potential treatment options or design strategies if deemed appropriate for non-potable uses.

While enteric pathogens such as Campylobacter jejuni, Salmonella spp., Cryptosporidium parvum. and Giardia lamblia in RHRW may occur infrequently from possums, birds and other animals present on roof-catchments [11,12], opportunistic pathogens such as Legionella spp., Mycobacterium avium complex (MAC), Acanthamoeba spp., Pseudomonas aeruginosa, and Naegleria fowleri may occur frequently in RHRW [6,13]. Concentrations of opportunistic pathogens can be consistently high in tank water, and additionally cause issues for tanks or barrels with long stagnation times or those located in tropical and sub-tropical regions [13]. Opportunistic pathogens can cause infections in people with underlying health conditions or in some cases infections in healthy individuals when exposed to high concentrations $[14,15]$. This group of pathogens causes respiratory, skin and soft tissue, eye, and brain infections in humans [16,17].

Studies that measured the quality and utilization of RHRW for domestic, potable, and non-potable uses tested for fecal indicator bacteria (FIB) such E. coli and Enterococcus spp. due to their regulatory importance and presumed association with enteric pathogens $[6,18,19]$. FIB are microorganisms found in the gut of warm-blooded animals, and generally are not considered pathogens themselves. However, their presence can indicate the potential presence of fecal material, which may harbor pathogens [20]. For drinking water standards according to the United States Environmental Protection Agency (USEPA), no more than $5 \%$ of samples should contain total coliforms (including E. coli and Enterococcus spp.) in a month, and for water systems collecting fewer than 40 routine samples/month, no more than one sample should be positive [21].

Currently, there are limited state regulations or guidelines specific to RHRW and these guidelines vary by location. For example, USEPA [22] and others [23-25] suggest up to 100 fecal coliforms $/ 100 \mathrm{~mL}$ or 200 fecal coliforms $/ 100 \mathrm{~mL}$ [26] is adequate water quality for indoor non-potable use or irrigation of non-food crops. For potable use, more stringent guidelines consistent with community or public water systems would be appropriate, with the absence of FIB and pathogens determined via testing every three months $[23,24,27,28]$. Guidelines can also be specific to the water use; for irrigation water in the United States, according to United States Food and Drug Administration (USFDA), the maximum permitted E. coli concentration is 126 colony forming units (CFU) $/ 100 \mathrm{~mL}$ (geometric mean, $n=5$ samples) and $235 \mathrm{CFU} / 100 \mathrm{~mL}$ for a single sample [28]. While FIB are presumed to indicate the occurrence of enteric pathogens, a lack of strong correlation has been demonstrated between FIB and either enteric or opportunistic pathogens [19].

Building materials such as lead paint or lead fittings can result in increased lead, copper, or zinc levels in RHRW [29]. Lead is considered one of the most important contaminants in terms of its potential human health effects, causing damage to the nervous system (especially in children), kidneys, and reproductive system $[30,31]$. The United States drinking water national primary standard (action level, in $10 \%$ of tap water samples) for lead is $15 \mu \mathrm{g} / \mathrm{L}$ [32], while federal irrigation standards are $5000 \mu \mathrm{g} / \mathrm{L}$ [22]. Zinc has a non-enforceable secondary maximum contaminant level of $5000 \mu \mathrm{g} / \mathrm{L}$ [33], while federal irrigation standards are $2000 \mu \mathrm{g} / \mathrm{L}$ [22].

Due to the lack of specific guidance on RHRB water quality in the USA, the objectives of this study were to investigate potential public health risks through: (i) a characterization of FIB, a range of potential enteric and opportunistic pathogens, lead, and zinc in barrel water; (ii) assessing the possible correlations between physico-chemical, survey, and rainfall parameters with the presence of FIB, potential opportunistic pathogens, and heavy metals in water samples collected from RHRB; 
(iii) determining potential exposures through a survey; and (iv) identifying potential risks through comparisons of contaminant concentrations with appropriate guidance or regulations.

\section{Materials and Methods}

\subsection{Study Areas and Survey}

A total of 38 samples were collected from 34 RHRB from various areas of urban and peri-urban Philadelphia between 2014 and 2016. A pilot round of sampling for 12 RHRB was conducted during November to December 2014 with one sample taken from each barrel. In June through August 2016, 26 additional water samples were collected from RHRB that were distinct from the pilot samples except for four barrels, which were sampled during both events. For the 2016 sampling event, a sanitary inspection was undertaken during sampling to confirm survey responses and identify factors (the presence of overhanging trees, TV aerials, and wildlife fecal contamination on the roof) in addition to physico-chemical water quality and FIB measurements. Sanitary inspection, physico-chemical parameter measurements, and FIB monitoring were not undertaken for the pilot round of barrel sampling. Participants were asked to fill out an online survey regarding their rain barrel characteristics in the 2016 study (Supplementary Materials Figure S1).

\subsection{Barrel Water Sampling}

For the 2014 round of sampling, the tap/spigot connected directly to the RHRB was wiped with $70 \%$ ethanol, and the water was run for $5 \mathrm{~s}$ before filling $1 \mathrm{~L}$ sterile polyethylene container for pathogen analysis. Three of the barrels were accessible only via a garden hose (RHRB 1, 5, and 11). For 2016 samples, the tap/spigot connected directly to the RHRB was wiped with $70 \%$ ethanol, and the water was run for $5 \mathrm{~s}$ before filling $1 \mathrm{~L}$ sterile polyethylene container for FIB analysis, $1 \mathrm{~L}$ sterile polyethylene container for pathogen analysis, and one $1 \mathrm{~L}$ detergent-washed (Micro-90, Burlington, NJ, USA) polyethylene container for lead and zinc analysis. One sample was accessible only via a garden hose (RHRB 25). One sample from 2016 (RHRB 20) was obtained directly from the top of the barrel as no spigot was present. Samples were transported on ice to the laboratory and kept at $4{ }^{\circ} \mathrm{C}$ until processing within 6-12 $\mathrm{h}$.

\subsection{Physico-Chemical Parameters}

Physico-chemical parameters were measured only for barrels sampled in 2016 . Temperature $\left({ }^{\circ} \mathrm{C}\right)$, conductivity $(\mu \mathrm{S})$, total dissolved solids $(\mathrm{ppm})$ and $\mathrm{pH}$ were measured immediately in samples taken from the spigots or top of barrels with a probe meter (Fisher-Scientific, Accumet AP85 Series, Pittsburgh, PA, USA). Total dissolved oxygen was also measured in-situ using a probe pen (SPER Scientific, Model 850045, Scottsdale, AZ, USA). Turbidity testing was performed using a LaMotte we/wi turbidity meter (Model 2020, Chestertown, MD, USA) and calibrated according to the manufacturer's instructions [34].

\subsection{Heavy Metals}

Metals were measured only for barrels sampled in 2016. For metals (lead and zinc) analysis, samples were acidified immediately upon arrival to the laboratory with $2 \%$ nitric acid $\left(\mathrm{HNO}_{3}\right)$ or until $\mathrm{pH}$ of 2.0. Samples were kept at $4{ }^{\circ} \mathrm{C}$ prior to examination by ICP-MS [35].

\subsection{Enumeration of Fecal Indicator Bacteria (FIB)}

FIB were measured for RHRB sampled in 2016. The membrane filtration method was used to process the barrel water samples for FIB enumeration. $100 \mathrm{~mL}$ of sample was filtered through $0.45-\mu \mathrm{m}$-pore-sized nitrocellulose membranes (Millipore, Burlington, MA, USA) and placed on modified mTEC agar (Difco, Detroit, MI, USA), and membrane-Enterococcus indoxyl- $\beta$-D-glucoside (mEI) agar (Difco) for the isolation of E. coli and Enterococcus spp. as described elsewhere [36-38]. 


\subsection{DNA Extraction and Assessment of PCR Inhibition}

Enteric and opportunistic pathogens were measured in all samples from both 2014 and 2016. For qPCR analysis of the potential pathogens, $500 \mathrm{~mL}$ of water sample from each barrel was filtered through a $0.45-\mu \mathrm{m}$-pore-size membrane (Millipore, Burlington, MA, USA). In case of membrane clogging during filtration, multiple membranes were used. The membranes were stored at $-80{ }^{\circ} \mathrm{C}$ until DNA extraction. DNA was extracted directly from the membranes using a PowerSoil ${ }^{\circledR}$ Soil DNA Kit (MO BIO Laboratories, Carlsbad, CA, USA) according to the manufacturer's instructions and stored at $-80{ }^{\circ} \mathrm{C}$ until use. DNA concentrations were determined using NanoDrop spectrophotometer (ND-1000, NanoDrop Technology, Wilmington, DE, USA). A Sketa22 real-time PCR assay was used to determine the likely presence of PCR inhibitors in the extracted DNA samples. The primer, probe and cycling conditions for the Sketa22 assay have been described elsewhere [6,39].

\subsection{Pathogen Quantification}

Acanthamoeba spp., Naegleria fowleri, Legionella spp., L. pneumophila, M. avium, M. intracellulare, Pseudomonas aeruginosa and C. jejuni were quantified using previously published probe-based qPCR assays [40-45]. The detailed methods previously used by the authors were replicated in this study and the full description is available elsewhere [6,13].

\subsection{Statistical Analysis}

Rainfall data was downloaded from the National Oceanic and Atmospheric Administration (NOAA) National Centers for Environmental Information [46]. The closest gauges for daily rainfall data with complete information available during the two sampling periods was determined by mapping gauges and RHRB, and determining the gauges which were present at the shortest geodesic distance from each barrel. This resulted in the use of data from two gauges from station USC00366886 (Philadelphia Franklin Institute, Philadelphia, PA, USA) and US1PAPH0008 (Philadelphia 2.7 WNW).

All pathogen datasets involved censored data with non-detect or non-quantifiable values [either between the lower limit of detection (LLOD) and lower limit of quantification (LLOQ) or above the upper limit of quantification (ULOQ)]. The LLOQ was considered the lowest concentration of target gene which could be quantified in triplicate by qPCR in a serially diluted standard. The LLOD was considered the dilution below the LLOQ. In this study, only some culture-based values were $>$ ULOQ. The use of statistical procedures for censored data is necessary to avoid biasing parameter estimates using other non-detect substitution methods [47]. Therefore, nonparametric Kendall's Tau correlations were computed to assess relationships among and between contaminants, and between contaminants and other parameters using the NADA package in the R software environment (www.r-project.org). Correlations were considered significant for an adjusted alpha value for each group of variables using the Bonferroni correction (significance level alpha/number of pairwise comparisons), with an alpha level of 0.05. Microbial parameters with fewer than five positive detections were excluded from the analysis. Correlations for potential opportunistic pathogens were computed using all (2014 and 2016) datasets. Data were plotted using GraphPad Prism version 6.07 (GraphPad Software Inc., La Jolla, CA, USA).

\section{Results}

\subsection{Pilot on-Site Observations and Survey/Sanitary Survey Data for 2016 Rain Barrels}

All thirty-four RHRB in the 2014 round and 2016 studies were constructed from polyethylene and all were used for gardening purposes (Supplementary Materials Table S1). Additionally, one of the pilot samples was used for toilet flushing (RHRB 3) and one was used for indoor plant watering (RHRB 9). Eleven of the 12 pilot rain barrels had capacities between 50 and 100 gallons, with one having greater than 100 gallon capacity and used to serve a community garden. During the winter of 2014, some RHRB users disconnected their barrels from the downspout. At the time of the pilot 
sampling, 4 of 12 of the RHRB had been disconnected from the downspout (RHRBs 6, 7, 8, and 10). RHRB 1 had been disconnected for the season and reconnected prior to the sampling event. None of the RHRB were equipped with a first-flush device.

The most common roofing material was asphalt shingle ( 26 roofs, $50 \%$ ). Other roof materials reported (with some combinations) included plastic sheeting ( 3 sites, $12 \%)$, tar (1 site, $4 \%$ ), slate (1 site, $4 \%$ ), and rubber ( 2 roofs, $8 \%$ ). Gutters were constructed most frequently from aluminum ( 24 sites, $92 \%$ ), steel ( 1 site, $4 \%)$, or plastic ( 1 site, $4 \%$ ). Twenty-two of the 26 rain barrels $(85 \%)$ sampled in 2016 had capacities between 50 to 100 gallons, and $8 \%$ of barrels sampled were $>100$ gallons. One barrel (RHRB 20) was disconnected at the time of sampling. Barrel ages ranged from $<1$ to 10 years. The majority of 2016 barrels had spigots which were $<6$ inches $(73 \%)$ from the bottom, with a smaller number that were $6-12$ inches $(15 \%)$ or $>12$ inches $(8 \%)$, and one barrel did not have a spigot $(4 \%)$. The barrel without a spigot was sampled by removing the top covering of the barrel. Two residences had a television aerial on the roof of the house (RHRB 5 and 23, RHRB 26), which can serve as a habitat for wildlife such as birds. Ten sampling sites (39\%) had signs of wildlife on the roof observed by the investigators or reported by barrel owners in the survey. Overhanging trees were present for twelve $(46 \%)$ of the 2016 sites.

Treatment of water contained in RHRB to improve water quality was not performed by any barrel owner, but three owners added treatment for mosquitos using larvicides such as Bacillus thuringensis (Bti) (RHRB 4, 5,23 and 34). Fourteen of the 26 barrels tested (54\%) were obtained from the Philadelphia Water Department, 9 were purchased from private vendors $(35 \%)$, one was constructed by the owner, and 10 were of unknown origin (39\%). Only four participants (15\%) had cleaned their barrel previously, and only two participants reported a cleaning frequency ( $>1-2$ years and $<3$ years). Five (19\%) participants had cleaned their gutters yearly, two $(8 \%)$ cleaned their gutters twice a year, and $20(77 \%)$ had never cleaned their gutters. Four sites $(15 \%)$ had gutter covers.

\subsection{Physico-Chemical Parameters and Fecal Indicator Bacteria (FIB) from 2016 Samplings}

Physico-chemical parameters for the twenty-six rain barrels tested in 2016 are shown in Table 1. $\mathrm{pH}$ for the samples ranged from 4.82 to 9.64 . Turbidity in the samples was generally low ( $<1$ NTU) but was extremely high for one sample (61.6 NTU). Conductivity and total dissolved solids (TDS) ranged from 37.8 to $648 \mu \mathrm{S}$ and 18.6 to $780 \mathrm{ppm}$, respectively. Dissolved oxygen ranged from 2.60 to $10.6 \mathrm{mg} / \mathrm{L}$.

Table 1. Physico-chemical water quality parameters for 2016 rainwater barrels.

\begin{tabular}{cc}
\hline Parameter & Mean (Range) \\
\hline $\mathrm{pH}$ & $6.25(4.82-9.64)$ \\
Conductivity $(\mu \mathrm{S})$ & $149(37.8-648)$ \\
Total Dissolved Solids (TDS) (ppm) & $101(18.6-780)$ \\
Temperature $\left({ }^{\circ} \mathrm{C}\right)$ & $26.6(22.5-30.5)$ \\
Dissolved Oxygen $(\mathrm{mg} / \mathrm{L})$ & $6.26(2.60-10.6)$ \\
Turbidity $(\mathrm{NTU})$ & $4.27(0.03-61.6)$ \\
\hline
\end{tabular}

Of the twenty-six RHRB systems tested for FIB in 2016, 16 (62\%) and 20 (77\%) were positive for E. coli and Enterococcus spp., respectively. Fourteen barrels (52\%) contained both E. coli and Enterococcus spp. Concentrations in positive samples ranged from 1 up to $>10^{3} \mathrm{CFU} / 100 \mathrm{~mL}$ of water (Figure 1). Five samples (19\%) exceeded the single sample maximum of 235 E. coli $/ 100 \mathrm{~mL}$. 


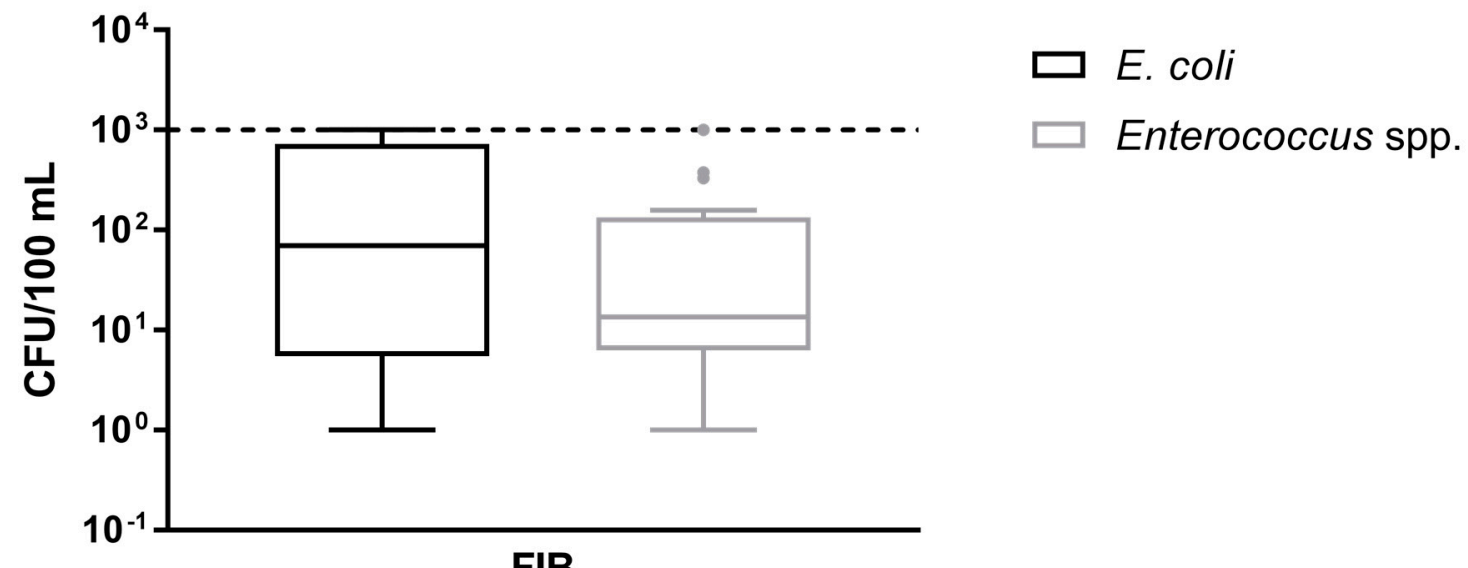

Figure 1. Fecal indicator bacteria (FIB) concentrations measured in positive samples from 2016 sampling. Upper limit of quantification shown by dotted line was 1000/100 mL.

\subsection{Concentrations of Potential Opportunistic Pathogens in 2014 and 2016 Tank Water Samples}

All RHRB samples were tested for potential enteric and opportunistic pathogens. The most prevalent potential opportunistic pathogen was Legionella spp. (57.9\% samples), followed by M. intracellulare (44.7\%), M. avium (21.1\%), Acanthamoeba spp. (18.4\%), P. aeruginosa (5.30\%), and C. jejuni $(2.60 \%)$ (Table 2). N. fowleri, and L. pneumophila were not detected in any sample. The highest (maximum) concentrations observed were for P. aeruginosa $\left(10^{7}\right.$ gene copies $\left./ \mathrm{L}\right)$, Acanthamoeba spp. $\left(10^{5}\right.$ gene copies/L), Legionella spp. $\left(10^{5}\right.$ gene copies/L), M. intracellulare $\left(10^{4}\right.$ gene copies/L), M. avium $\left(10^{3}\right.$ gene copies/L), and C. jejuni $\left(10^{2}\right.$ gene copies/L) (Figure 2).

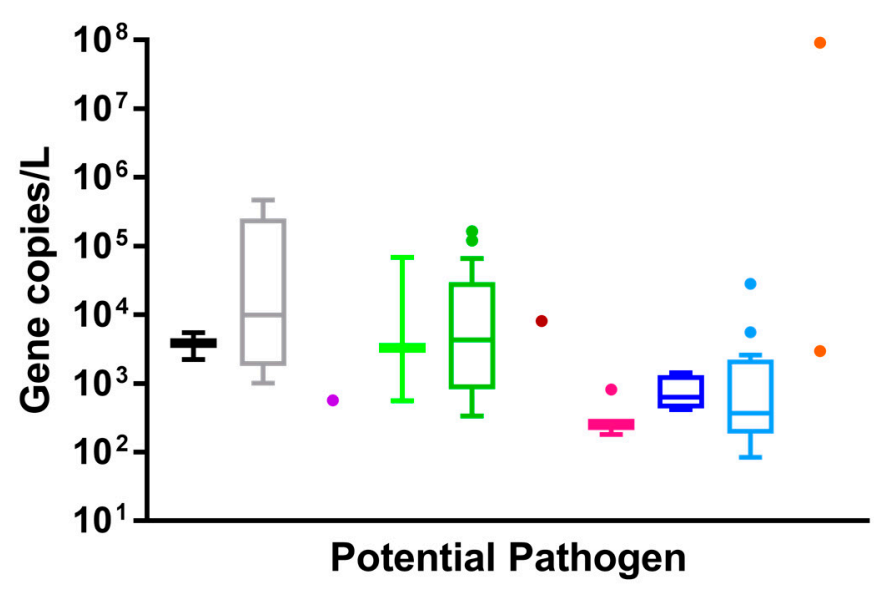

Acanthamoeba spp. 2014 Acanthamoeba spp. 2016

$\square$ C jejuni 2016

$\square$ Legionella spp. 2014

$\square$ Legionella spp. 2016

$\square$ M. avium 2014

$\square$ M. avium 2016

$\square$ M. intracellulare 2014

$\square$ M. intracellulare 2016

$\square$ P. aeruginosa 2016

Figure 2. Potential pathogen concentrations measured in positive samples from 2014 and 2016 sampling. Parameters of box plot shown are 25th, 50th, and 75th percentiles with whiskers extending to 5th and 95th percentiles for datasets with more than three observations. Data with fewer than 3 positive detections are shown as points. 
Table 2. Concentrations of FIB and pathogens and occurrence of metals in water samples collected from roof-harvested rainwater barrels (RHRB) in 2014 and 2016.

\begin{tabular}{cccc}
\hline Parameter (Units) & $\begin{array}{c}\text { Lower Limit of } \\
\text { Quantification (LLOQ) }\end{array}$ & $\begin{array}{c}\text { Mean of Positive Samples } \\
\text { (Range) }\end{array}$ & $\begin{array}{c}\text { No. of Positive } \\
\text { Sample/Total (\%) }\end{array}$ \\
\hline E. coli/100 mL & 1 & $2.92 \times 10^{2}\left(1->10^{3}\right)^{\mathrm{a}}$ & $16 / 26(61.5)$ \\
Enterococcus spp./100 mL & 1 & $1.55 \times 10^{2}\left(1->10^{3}\right)^{\mathrm{a}}$ & $20 / 26(76.9)$ \\
Acanthamoeba spp./L & 333 & $7.48 \times 10^{4}\left(1.01 \times 10^{3}-4.68 \times 10^{5}\right)$ & $7 / 38(18.4)$ \\
C. jejuni/L & 33.3 & $2.82 \times 10^{2}$ & $1 / 38(2.6)$ \\
Legionella spp./L & 333 & $2.47 \times 10^{4}\left(3.37 \times 10^{2}-1.63 \times 10^{5}\right)$ & $22 / 38(57.9)$ \\
L. pneumophila/L & 33.3 & $\mathrm{ND}^{\mathrm{b}}$ & $0 / 38(0)$ \\
M. avium/L & 33.3 & $1.30 \times 10^{3}\left(1.80 \times 10^{2}-8.10 \times 10^{3}\right)$ & $8 / 38(21.1)$ \\
M. intracellulare/L & 33.3 & $2.59 \times 10^{3}\left(8.41 \times 10^{1}-2.83 \times 10^{4}\right)$ & $17 / 38(44.7)$ \\
N. fowleri/L & 33.3 & $\mathrm{ND}$ & $0 / 38(0)$ \\
P. aeruginosa/L & 333 & $4.57 \times 10^{7}\left(2.95 \times 10^{3}-9.14 \times 10^{7}\right)$ & $2 / 38(5.3)$ \\
Lead $(\mu \mathrm{g} / \mathrm{L})$ & 3 & $79.4(3-1282)$ & $23 / 26(88.5)$ \\
Zinc $(\mu \mathrm{Hg} / \mathrm{L})$ & 25 & $255.3(29-2660)$ & $23 / 26(88.5)$ \\
\hline
\end{tabular}

Notes: ${ }^{a}$ Upper limit of quantification $\left(10^{3} \mathrm{CFU} / 100 \mathrm{~mL}\right)$ was substituted for TNTC values for calculation of mean;

${ }^{\mathrm{b}}$ Not detected.

\subsection{Lead and Zinc}

Lead and zinc were each observed in $88.5 \%$ of RHRB. They were present simultaneously in 21 barrels (81\%). Concentrations of lead in positive samples ranged from $3 \mu \mathrm{g} / \mathrm{L}$ to $1282 \mu \mathrm{g} / \mathrm{L}$, while zinc concentrations in positive samples ranged from $29 \mu \mathrm{g} / \mathrm{L}$ to $2660 \mu \mathrm{g} / \mathrm{L}$ (Figure 3). All samples were below the recommended lead concentration for produce irrigation water of $5000 \mu \mathrm{g} / \mathrm{L}$, while a single sample exceeded the zinc irrigation standard of $2000 \mu \mathrm{g} / \mathrm{L}$ [22].

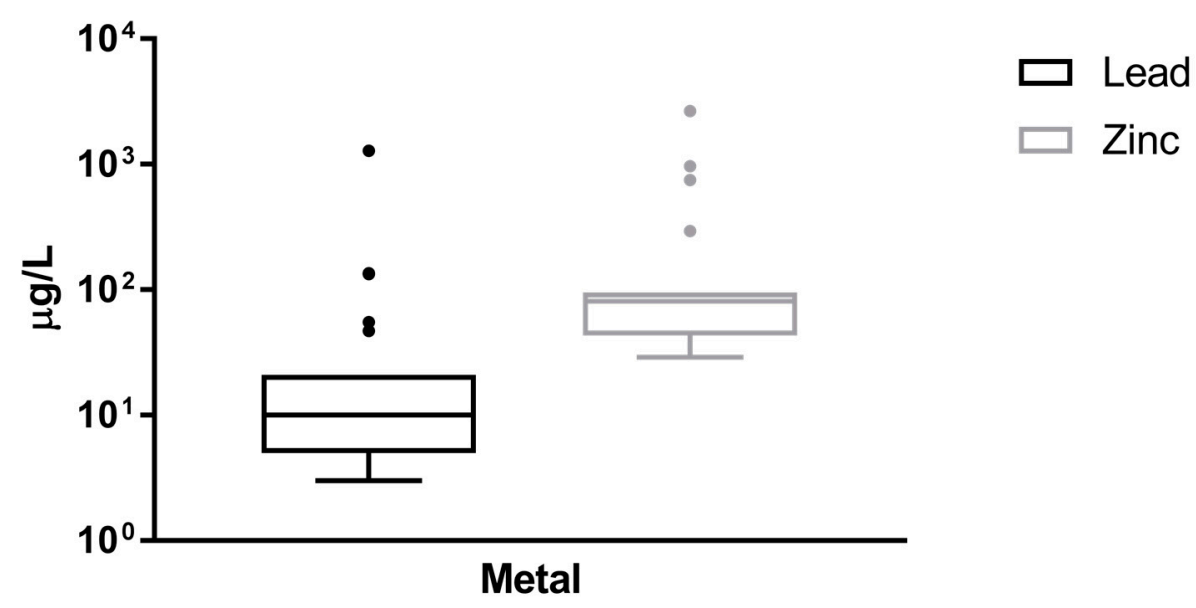

Figure 3. Metal concentrations measured in positive samples from 2016 sampling. Parameters of box plot shown are 25th, 50th, and 75th percentiles with whiskers extending to 5th and 95th percentiles.

\subsection{Correlations among Contaminants, and between Contaminants and Physico-Chemical Parameters}

A significant moderate correlation was observed between E. coli and Enterococcus spp. $(\tau=0.520)$ (Table 3). Few correlations were observed between FIB, potential opportunistic pathogens, or heavy metals with physico-chemical parameters (Table 4). Significant moderate correlations were observed between lead and conductivity $(\tau=0.403)$ as well as total dissolved solids $(\tau=0.440)$. No microbial parameter was significantly correlated with a physico-chemical parameter. 
Table 3. Correlations between opportunistic pathogens and fecal indicators in RHRB. FIB correlations shown are for 2016 data only. Parameters with fewer than 5 positive detections were excluded. Significant values are bold-faced, with $\alpha_{\text {corrected }}=0.05 / 7=0.007$

\begin{tabular}{|c|c|c|c|c|c|c|c|}
\hline Parameter [Kendall's Tau, $(P)]^{\text {a }}$ & E. coli & Enterococcus spp. & Acanthamoeba spp. & Legionella spp. & M. avium & M. intracellulare & Lead \\
\hline Enterococcus spp. & $0.520(<0.001)$ & & & & & & \\
\hline Acanthamoeba spp. & $0.015(0.880)$ & $-0.009(0.942)$ & & & & & \\
\hline Legionella spp. & $-0.160(0.235)$ & $-0.102(0.470)$ & $-0.014(0.848)$ & & & & \\
\hline M. avium & $-0.157(0.114)$ & $-0.031(0.783)$ & $0.010(0.841)$ & $0.161(0.025)$ & & & \\
\hline M. intracellulare & $0.102(0.411)$ & $0.068(0.602)$ & $0.058(0.358)$ & $-0.118(0.225)$ & $-0.048(0.480)$ & & \\
\hline Lead & $0.271(0.045)$ & $0.246(0.077)$ & $0.151(0.081)$ & $0.228(0.101)$ & $0.009(0.951)$ & $0.025(0.862)$ & \\
\hline Zinc & $0.061(0.645)$ & $0.102(0.476)$ & $0.059(0.516)$ & $0.129(0.358)$ & $-0.052(0.627)$ & $-0.006(0.980)$ & $0.295(0.035)$ \\
\hline
\end{tabular}

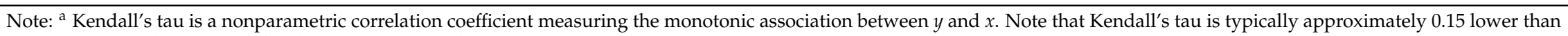
Spearman's $\rho$ and Pearson's $r$ for the same strength of association.

Table 4. Correlations between contaminants and physico-chemical parameters for 2016 data. Microbiological parameters with fewer than 5 positive detections were excluded. Significant values are bold-faced, with $\alpha_{\text {corrected }}=0.05 / 6=0.008$

\begin{tabular}{|c|c|c|c|c|c|c|}
\hline Parameter [Kendall's Tau, $(P)]^{\mathrm{a}}$ & $\mathrm{pH}$ & Conductivity $(\mu S)$ & Total Dissolved Solids (ppm) & Temp. $\left({ }^{\circ} \mathrm{C}\right)$ & Dissolved Oxygen (mg/L) & Turbidity (NTU) \\
\hline E. coli & $-0.222(0.103)$ & $0.086(0.535)$ & $0.123(0.370)$ & $-0.052(0.713)$ & $0.080(0.565)$ & $0.193(0.168)$ \\
\hline Enterococcus spp. & $-0.148(0.295)$ & $0.154(0.275)$ & $0.191(0.175)$ & $-0.062(0.672)$ & $0.157(0.265)$ & $0.167(0.249)$ \\
\hline Acanthamoeba spp. & $0.114(0.194)$ & $0.132(0.131)$ & $0.182(0.037)$ & $-0.019(0.857)$ & $0.012(0.914)$ & $0.047(0.578)$ \\
\hline Legionella spp. & $0.129(0.359)$ & $0.135(0.336)$ & $0.080(0.576)$ & $0.074(0.607)$ & $0.006(0.982)$ & $0.010(0.962)$ \\
\hline M. avium & $-0.006(0.976)$ & $0.025(0.832)$ & $0.012(0.928)$ & $-0.062(0.564)$ & $-0.095(0.362)$ & $0.117(0.247)$ \\
\hline M. intracellulare & $-0.071(0.588)$ & $0.080(0.538)$ & $0.105(0.416)$ & $-0.003(>0.999)$ & $-0.025(0.863)$ & $<0.001(>0.999)$ \\
\hline Lead & $0.059(0.690)$ & $0.403(0.004)$ & $0.440(0.002)$ & $0.231(0.101)$ & $-0.077(0.595)$ & $0.032(0.026)$ \\
\hline Zinc & $-0.025(0.877)$ & $0.037(0.808)$ & $0.098(0.494)$ & $0.074(0.611)$ & $0.074(0.611)$ & $0.197(0.175)$ \\
\hline
\end{tabular}

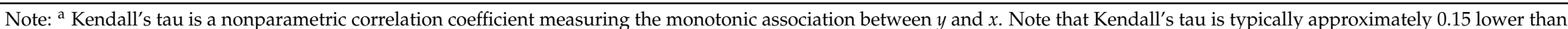
Spearman's $\rho$ and Pearson's $r$ for the same strength of association. 


\subsection{Correlations between Contaminants, Meteorological, and Survey Parameters}

Rainfall occurred within 5 days of sampling for all sites, and 15/38 sampling events had rainfall on the sampling day (Supplementary Materials Table S1). The average rainfall at each site during the 7 days prior to the sampling event was 24.6 inches, ranging from 0.8 inches to 47.7 inches (Supplementary Materials Table S1). No significant correlations were observed between contaminants and rainfall, spigot distance, or barrel age (Supplementary Materials Table S2). Due to the limited number of samples accessed from a hose $(n=3)$, number of people who had ever cleaned their barrel $(n=4)$, similarity in size for all barrels (50-100 gallons), and similarity in gutter material (24/26 in the 2016 were made from aluminum), no statistical analysis was conducted for these parameters. Similarly, of those who reported their roof type, most $(n=17 / 35)$ were constructed from asphalt or tar, or of unknown material $(n=11 / 35)$. Information for dichotomous variables of overhanging trees and presence of wildlife were similarly sparse when compared with the number of positive microbiological detection events for determining statistical association in each category. Given this limited information, a comparison of the number of positive detections in each category is shown in Table 5. Overhanging trees were associated with a greater percentage of positive detections for Enterococcus spp., P. aeruginosa and C. jejuni (although P. aeruginosa and C. jejuni had only a single detection for each), and a slightly greater percentage for $M$. intracellulare. Overhanging trees were associated with a greater percentage of negative detections for Acanthamoeba spp., Legionella spp., and M. avium and slightly for E. coli. The presence of wildlife was associated with a greater percentage of positive detections for $E$. coli and M. intracellulare, however, only 3/13 survey respondents reported that there was no wildlife present at the site.

Table 5. Number of microbiological detections for sites where overhanging trees $(n=12)$ or presence of wildlife $(n=10)$ were observed (percentage of total reported yes or no responses in each survey category that had positive microbiological detections).

\begin{tabular}{ccccc}
\hline \multirow{2}{*}{ Parameter } & \multicolumn{2}{c}{ Overhanging Trees } & \multicolumn{2}{c}{ Presence of Wildlife } \\
\cline { 2 - 5 } & Yes $(\boldsymbol{n = 1 2})$ & No $(\boldsymbol{n = 1 3 )}$ & Yes $(\boldsymbol{n = 1 0 )}$ & No $(\boldsymbol{n = 3 )}$ \\
\hline E. coli & $11(91.7)$ & $12(92.3)$ & $7(70.0)$ & $2(66.7)$ \\
Enterococcus spp. & $11(91.7)$ & $8(61.5)$ & $8(80.0)$ & $3(100)$ \\
Acanthamoeba spp. & $1(8.33)$ & $4(30.8)$ & $1(10.0)$ & $1(33.3)$ \\
C. jejuni & $1(8.33)$ & $0(0)$ & $0(0)$ & $0(0)$ \\
Legionella spp. & $7(58.3)$ & $11(84.6)$ & $4(40.0)$ & $3(100)$ \\
M. avium & $2(16.7)$ & $4(30.8)$ & $0(0)$ & $1(33.3)$ \\
M. intracellulare & $6(50.0)$ & $6(46.2)$ & $7(70.0)$ & $1(33.3)$ \\
P. aeruginosa & $1(8.3)$ & $0(0)$ & $0(0)$ & $0(0)$ \\
\hline
\end{tabular}

\section{Discussion}

Roof-harvested rainwater has been shown to be contaminated with multiple types of microbiological, chemical, and heavy metal pollutants [29], raising concerns regarding potential public health risks when RHRB owners are exposed to rainwater during its use. In the current study of 38 urban and peri-urban Philadelphia RHRB, gardening was the most frequently reported use of stored rainwater, indicating the most relevant potential public health risks are likely to be from exposure to RHRW during garden hose usage [48] or consumption of raw produce irrigated with RHRW [49]. The use of rainwater for gardening is recommended primarily for non-edible plants [3]; however, residents also reported using the rainwater for edible produce eaten raw such as lettuce, herbs, and tomatoes. This indicates that some pathogens might not be completely inactivated if produce is consumed raw. Additionally, exposure to metals or other contaminants could occur from consumption. The only other use of RHRW reported in the current study was indoor non-potable use. Indoor use of rainwater was rare, with indoor plant-watering and toilet flushing reported at two sites. However, some risks during 
toilet flushing may be incurred from exposure to both fecal and opportunistic pathogens during the generation of aerosols when toilets are flushed [49,50].

As gardening was the most common use of RHRB, water quality parameters were compared to USFDA and USEPA irrigation standards to determine potential risks. Lead and zinc were observed in the majority of RHRB at low concentrations, below USEPA irrigation standards of $5000 \mu \mathrm{g} / \mathrm{L}$ and $2000 \mu \mathrm{g} / \mathrm{L}$ for lead and zinc, respectively, with only one sample exceeding the value for zinc [22]. This is consistent with previous findings [51], indicating low levels of lead (highest mean $3.7 \mu \mathrm{g} / \mathrm{L}$ ) and zinc (highest mean $78.7 \mu \mathrm{g} / \mathrm{L}$ ) in suburban and urban RHRB.

The high prevalence ( $62 \%$ and $77 \%$ positive for E. coli and Enterococcus spp., respectively) and concentrations of FIB detected (up to $>10^{3}$ E. coli and Enterococcus spp. $/ 100 \mathrm{~mL}$ ) indicated the presence of fecal material in RHRB. Five (19\%) samples exceeded the USFDA irrigation single sample maximum of 235 E. coli/ $100 \mathrm{~mL}$ [28], indicating that water stored in the RHRB would generally not meet irrigation water standards for produce intended for human consumption. If the geometric mean is computed by substituting the upper limit of quantification for too numerous to count (TNTC) values, the resulting mean E. coli concentration $(51 / 100 \mathrm{~mL})$ would not exceed the USFDA allowable geometric mean of $126 \mathrm{CFU} / 100 \mathrm{~mL}$ in 5 samples [28]. A prevalence of up to $79 \%$ and $83 \%$ has been previously observed for E. coli and Enterococcus spp. in rainwater tanks, respectively, indicating that the prevalence observed in the current study was not unusual [52]. The presence of FIB in RHRW is common, as FIB can enter RHRW/RHRB from the feces of birds, insects, small mammals, and other animals present on roof surface catchment areas, gutters, or openings in the top of partially sealed barrels that are covered with wire mesh but not completely sealed [19]. Soil dusts or other debris could also potentially introduce FIB into barrels through the same routes.

Acanthamoeba spp., C. jejuni, Legionella spp., M. avium, M. intracellulare, and P. aeruginosa were observed in RHRB from the Philadelphia area, while N. fowleri and L. pneumophila were not detected in any barrel water. Previously observed concentrations of Acanthamoeba spp. $\left(6.6 \times 10^{5} / \mathrm{L}\right)$, Legionella spp. $\left(3.1 \times 10^{6} / \mathrm{L}\right)$, M. avium $\left(1.1 \times 10^{5} / \mathrm{L}\right)$, M. intracellulare $\left(6.8 \times 10^{5} / \mathrm{L}\right)$, and P. aeruginosa $\left(9.6 \times 10^{5} / \mathrm{L}\right)$ from Australian RHRW tanks are 1-2 orders of magnitude higher than those observed in the current RHRB study. Campylobacter spp. (up to $41 \%$ of samples, $n=27)$ and $C$. jejuni $(0.4 \%$ of samples, $n=214$ ) have been previously detected in RHRW samples [48,53], but not quantified. Limited observations of the quality of water stored in RHRB have been made in the continental US [54-56] and have focused on FIB total coliforms and heterotrophic plate counts.

The potential pathogens detected can cause respiratory ( $M$. avium and $M$. intracellulare; L. pneumophila was not detected, but other species from the genus Legionella can cause respiratory illness [57]), eye (Acanthamoeba spp.), gastrointestinal (C. jejuni), and skin (P. aeruginosa) illnesses through inhalation or ingestion routes, or contact with eye tissue in the case of Acanthamoeba spp. [16]. While irrigation standards do not address opportunistic pathogens or Campylobacter spp. [28], previous risk assessments of L. pneumophila, M. avium, and M. intracellulare suggest that exposure to aerosols during garden hosing or toilet flushing, and consumption of produce irrigated with RHRW can present risks for public health $[48,49]$. Due to the absence of L. pneumophila and lower concentrations of M. avium and M. intracellulare detected in the current study compared to the one used to develop input distributions for the previous quantitative microbial risk assessment (QMRA) [6], a new QMRA is recommended to assess risks in Philadelphia RHRB. Additionally, uses and their relative frequencies are different for US populations compared to those from Australia [6]. C. jejuni is a fecal-oral pathogen that can be of concern for food crop irrigation or toilet flushing using rainwater [58]. Campylobacter spp. and Campylobacter fetus have previously been associated with outbreaks linked to the use of RHRW; however, these associations were due to direct potable consumption of rainwater [59,60]. Detection of C. jejuni was rare (1/38 samples) in Philadelphia RHRB, suggesting that associated exposures are likely to be rare. It is noted here that qPCR methods provide information on the number of gene copies of pathogens in a sample. The presence of gene copies indicates that a pathogen was present at some 
time in a rain barrel; however, it does not indicate whether the quantified pathogens are alive or dead, and whether they are infectious at that particular time to a person who is potentially exposed.

There are several factors which can affect the presence of opportunistic pathogens in RHRB. As opportunistic pathogens are not usually fecal-associated, the initial inoculum in rain barrels may play less of a role than the conditions and design factors within barrels that contribute to growth or decay. The initial inoculum of pathogens could be affected additionally by pre-filters or mesh screens if any are used. In particular, the distance between the barrel spigot and the bottom of the barrel can impact the regrowth and transport of microorganisms contained in sediments within the barrel and the rate of transfer of sediments to the bulk water drawn from the barrel through the spigot; however no statistical associations between spigot distance and microbiological parameters were shown in this study. Sediments and biofilms may harbor opportunistic pathogens [61], and a smaller spigot distance could indicate an increased potential for pathogens to enter the outflowing water. In particular, biofilms and sediments combined with stagnant, warm waters can encourage pathogen (re)growth [16]. For logistical reasons, sampling times differed between barrels, and growth or decay could have occurred due to local environmental factors such as rain barrel water temperature. This can be influenced by the orientation of a barrel and degree of sunlight received, which differed from property to property (see Supplementary Materials Table S1). Most barrels in the study had spigot distances $<6$ inches. However, further investigation is warranted to assess the impact of design features on pathogen occurrence and growth in small-scale barrels.

FIB were not correlated with potential opportunistic pathogens in RHRB; this is similar to previous observations in rainwater tanks in Australia [13] and may be due to differences between the preferred growth conditions of opportunistic pathogens compared to FIB, differences in decay rates, or differences in the origins of each pathogen group (ubiquitous in water vs. fecal origin). No correlations were observed between physico-chemical parameters, rainfall during the 7 days prior (including the sampling day), or time since the last rainfall event, and any microbiological parameter. The lack of correlation among water quality parameters indicates that better characterization of factors contributing to the degradation of microbiological quality in Philadelphia rainwater barrels is needed, and larger statistical samples would allow for further comparison. The observed lack of correlations may be due to the relatively small number of positive detections for FIB and opportunistic pathogens, and could require a larger dataset for accurately assessing correlations. The minimum sample size necessary to perform a correlation varies and will depend on the magnitude of the population correlation, width of the confidence interval, and desired $\alpha$; for small values of Kendall's Tau this is likely to be greater than 46 samples, but for high correlations could be as few as 8 samples [62].

Harvesting rainwater through rain barrel systems is one way of reducing stormwater runoff, and is currently employed in urban areas among other investments in green infrastructure [63]. Information regarding harvested rainwater quality is useful to urban planners, engineers, utility managers, and residents who are concerned with water conservation and cost savings. Characterization of contaminants present and circumstances under which they occur can improve guidelines, regulations, and maintenance recommendations concerning small-scale harvested RHRB. Additional information is needed regarding the feasibility, cost, and health risk-reduction benefits of point-of-use devices or other interventions such as first-flush devices, cleaning and disinfecting rain barrels, and using mesh screens to prevent debris from entering the barrel in these small-scale systems under varied environmental conditions and maintenance schemes. Although the risk from enteric pathogens is likely to be low for municipal irrigation [64,65], risks due to opportunistic pathogens may be higher due to non-potable uses such as gardening, and further investigation would be beneficial.

Supplementary Materials: The following are available online at http://www.mdpi.com/2073-441/10/2/92/s1, Figure S1: Online survey sent to 2016 Philadelphia rainwater study participants, Table S1: Summary of sampling sites, online survey, and sanitary survey, Table S2: Correlations between contaminants and meteorological or survey parameters. 
Acknowledgments: This work was supported by the Drexel Raising Interest in STEM Education (RISE) Program. RISE@Drexel was a United States Department of Education-funded program in the framework of the Minority Science \& Engineering Improvement Program (MSEIP) award P120A130035. Drexel was a sub-contractor to Community College of Philadelphia tasked with providing the summer research experience and organizing an annual career panel discussion and faculty-staff roundtable discussion. The authors would like to thank Antonio Kontsos, Daniel Christe, Brian Wisner, and Jay Bhatt, of Drexel University, as well as Renee Medley, Linda Powell, and Alex Gontar of the Community College of Philadelphia. The authors are grateful to residents for providing access to their barrels for water sampling.

Author Contributions: Kerry A. Hamilton designed study, conducted sampling and lab work, analyzed correlations, and wrote paper; Kerrianne Parrish conducted sampling, lab work, and analyzed data; Warish Ahmed analyzed pathogen samples; Charles N. Haas edited paper and statistical analysis.

Conflicts of Interest: The authors declare no conflict of interest.

\section{References}

1. Hanjra, M.A.; Blackwell, J.; Carr, G.; Zhang, F.; Jackson, T.M. Wastewater irrigation and environmental health: Implications for water governance and public policy. Int. J. Hyg. Environ. Health 2007, 215, $255-269$. [CrossRef] [PubMed]

2. Thomas, R.B.; Kirisits, M.J.; Lye, D.J.; Kinney, K.A. Rainwater harvesting in the United States: A survey of common system practices. J. Clean. Prod. 2014, 75, 166-173. [CrossRef]

3. Philadelphia Water Department (PWD). Philadelphia Water Department Rain Check. 2017. Available online: http:/ / www.phillywatersheds.org/whats_in_it_for_you/residents/raincheck/rain-barrel (accessed on 15 June 2016).

4. Ahmed, W.; Hodgers, L.; Sidhu, J.P.S.; Toze, S. Fecal indicators and zoonotic pathogens in household drinking water taps fed from rainwater tanks in Southeast Queensland, Australia. Appl. Environ. Microbiol. 2012, 78, 219-226. [CrossRef] [PubMed]

5. Dobrowsky, P.H.; De Kwaadsteniet, M.; Cloete, T.E.; Khan, W. Distribution of indigenous bacterial pathogens and potential pathogens associated with roof-harvested rainwater. Appl. Environ. Microbiol. 2014, 80, 2307-2316. [CrossRef] [PubMed]

6. Hamilton, K.A.; Ahmed, W.; Palmer, A.; Sidhu, J.P.S.; Hodgers, L.; Toze, S.; Haas, C.N. Public health implications of Acanthamoeba and multiple potential opportunistic pathogens in roof-harvested rainwater tanks. Environ. Res. 2016, 150, 320-327. [CrossRef] [PubMed]

7. Daoud, A.K.; Swaileh, K.M.; Hussein, R.M.; Matani, M. Quality assessment of roof-harvested rainwater in the West Bank, Palestinian Authority. J. Water Health 2011, 9, 525-533. [CrossRef] [PubMed]

8. Uba, B.N.; Aghogho, O. Rainwater quality from different roof catchments in the Port Harcourt district, Rivers State, Nigeria. J. Water Supply Res. Technol. 2000, 49, 281-288.

9. Alves, F.; Köchling, T.; Luz, J.; Santos, S.M.; Gavazza, S. Water quality and microbial diversity in cisterns from semiarid areas in Brazil. J. Water Health 2014, 12, 513-525. [CrossRef] [PubMed]

10. Despins, C.; Farahbakhsh, K.; Leidl, C. Assessment of rainwater quality from rainwater harvesting systems in Ontario, Canada. J. Water Supply Res. Technol. 2009, 58, 117-134. [CrossRef]

11. Ahmed, W.; Sidhu, J.P.S.; Toze, S. An attempt to identify the likely sources of Escherichia coli harboring toxin genes in rainwater tanks. Environ. Sci. Technol. 2012, 46, 5193-5197. [CrossRef] [PubMed]

12. Chilvers, B.L.; Cowan, P.E.; Waddington, D.C.; Kelly, P.J.; Brown, T.J. The prevalence of infection of Giardia spp. and Cryptosporidium spp. in wild animals on farmland, southeastern North Island, New Zealand. Int. J. Environ. Health Res. 1998, 8, 59-64. [CrossRef]

13. Hamilton, K.A.; Ahmed, W.; Palmer, A.; Smith, K.; Toze, S.; Haas, C.N. A seasonal assessment of opportunistic premise plumbing pathogens in roof-harvested rainwater tanks. Environ. Sci. Technol. 2017, 51, 1742-1753. [CrossRef] [PubMed]

14. Chan, E.D.; Iseman, M.D. Underlying host risk factors for nontuberculous mycobacterial lung disease. In Seminars in Respiratory and Critical Care Medicine; Thieme Medical Publishers: New York, NY, USA, 2013; pp. 110-123.

15. Falkinham, J.O., III. Ecology of nontuberculous Mycobacteria-where do human infections come from? In Seminars in Respiratory and Critical Care Medicine; Thieme Medical Publishers: New York, NY, USA, 2013; pp. 95-102. 
16. Falkinham, J.O., III; Hilborn, E.D.; Arduino, M.J.; Pruden, A.; Edwards, M.A. Epidemiology and ecology of opportunistic premise plumbing pathogens: Legionella pneumophila, Mycobacterium avium, and Pseudomonas aeruginosa. Environ. Health Perspect. 2015, 123, 749-758. [CrossRef] [PubMed]

17. Bartrand, T.A.; Causey, J.J.; Clancy, J.L. Naegleria fowleri: An emerging drinking water pathogen. J. Am. Water Works Assoc. 2014, 10, E418-E432. [CrossRef]

18. Albrechtsen, H.J. Microbiological investigations of rainwater and graywater collected for toilet flushing. Water Sci. Technol. 2002, 46, 311-316. [PubMed]

19. Ahmed, W.; Goonetilleke, A.; Gardner, T. Implications of faecal indicator bacteria for the microbiological assessment of roof-harvested rainwater quality in Southeast Queensland, Australia. Can. J. Microbiol. 2010, 56, 471-479. [CrossRef] [PubMed]

20. Cox, P.; Griffith, M.; Angles, M.; Deere, D.; Ferguson, C. Concentrations of pathogens and indicators in animal feces in the Sydney watershed. Appl. Environ. Microbiol. 2005, 71, 5929-5934. [CrossRef] [PubMed]

21. United States Environmental Protection Agency (USEPA). National Primary Drinking Water Regulations; Office of Groundwater and Drinking Water (OGWDW): Washington, DC, USA, 2009.

22. United States Environmental Protection Agency (USEPA). Guidelines for Water Reuse; Office of Wastewater Management, Office of Water National Risk Management Research Laboratory, US Agency for International Development: Washington, DC, USA; Cincinnati, OH, USA, 2012.

23. The Texas Water Development Board. The Texas Manual on Rainwater Harvesting; The Texas Water Development Board: Austin, TX, USA, 2005.

24. Texas Rainwater Harvesting Evaluation Committee. Rainwater Harvesting Potential and Guidelines for Texas Report to the 80th Legislature; The Texas Water Development Board: Austin, TX, USA, 2006.

25. Kloss, C. Managing Wet Weather with Green Infrastructure Municipal Handbook: Rainwater Harvesting Policies. Available online: https:/ / dep.wv.gov/WWE/Programs/stormwater/MS4/guidance/handbooks/ Pages/default.aspx (accessed on 15 January 2018).

26. NSF/ANSI 350 350-2011 (NSF). Onsite Residential and Commercial Water Reuse Treatment Systems; National Sanitation Foundation: Ann Arbor, MI, USA, 2011.

27. Macomber, P.S. Guidelines on Rainwater Catchment Systems for Hawaii; University of Hawaii at Manoa, College of Tropical Agriculture \& Human Resources: Manoa, HI, USA, 2004.

28. United States Food and Drug Administration (USFDA). Food Safety Modernization Act: Proposed Rule for Produce: Standards for the Growing, Harvesting, Packing, and Holding of Produce for Human Consumption; Food and Drug Administration: College Park, MD, USA, 2011.

29. Abbasi, T.; Abbasi, S.A. Sources of pollution in rooftop rainwater harvesting systems and their control. Crit. Rev. Environ. Sci. Technol. 2011, 41, 2097-2167. [CrossRef]

30. Agency for Toxic Substances and Disease Registry (ATSDR). Lead-ToxFAQs; Agency for Toxic Substances and Disease Registry, Division of Toxicology and Human Health Sciences: Atlanta, GA, USA, 2007.

31. Banks, E.C.; Ferretti, L.E.; Shucard, D.W. Effects of low level lead exposure on cognitive function in children: A review of behavioral, neuropsychological and biological evidence. Neurotoxicology 1997, 18, 237-281. [PubMed]

32. United States Environmental Protection Agency (USEPA). 40 CFR Parts 141 and 142 National Primary Drinking Water Regulations for Lead and Copper: Short Term Regulatory Revisions and Clarifications; Final Rule; Cornell Law School: Ithaca, NY, USA, 2007.

33. United States Environmental Protection Agency (USEPA). Drinking Water Regulations and Contaminants; United States Environmental Protection Agency: Washington, DC, USA, 2009.

34. LaMotte. LaMotte 2020 we/wi Turbidimeter; 1970-EPA, 1970-ISO; LaMotte: Chestertown, MD, USA, 2012.

35. United States Environmental Protection Agency (USEPA). Method 200.8: Determination of Trace Elements in Water and Wastes by Inductively Coupled Plasma-Mass Spectrometry; Revision 5.4; Environmental Monitoring Systems Laboratory, Office of Research and Development: Cincinnati, OH, USA, 1994.

36. Ahmed, W.; Brandes, H.; Gyawali, P.; Sidhu, J.P.S.; Toze, S. Opportunistic pathogens in roof-captured rainwater samples, determined using quantitative PCR. Water Res. 2014, 53, 361-369. [CrossRef] [PubMed]

37. United States Environmental Protection Agency (USEPA). Method 1600: Membrane Filter Test Method for Enterococci in Water; Office of Water: Washington, DC, USA, 1997. 
38. United States Environmental Protection Agency (USEPA). Method 1603: Escherichia coli (E. coli) in Water by Membrane Filtration Using Modified Membrane-Thermotolerant Escherichia coli Agar (Modified mTEC); Office of Water: Washington, DC, USA, 2002.

39. Haugland, R.A.; Siefring, S.C.; Wymer, L.J.; Brenner, K.P.; Dufour, A.P. Comparison of Enterococcus measurements in freshwater at two recreational beaches by quantitative polymerase chain reaction and membrane filter culture analysis. Water Res. 2005, 39, 559-568. [CrossRef] [PubMed]

40. Chern, E.C.; King, D.; Haugland, R.; Pfaller, S. Evaluation of quantitative polymerase chain reaction assays targeting Mycobacterium avium, M. intracellulare, and M. avium subspecies paratuberculosis in drinking water biofilms. J. Water Health 2015, 13, 131-139. [CrossRef] [PubMed]

41. Nazarian, E.J.; Bopp, D.J.; Saylors, A.; Limberger, R.J.; Musser, K.A. Design and implementation of a protocol for the detection of Legionella in clinical and environmental samples. Diagn. Microbiol. Infect. Dis. 2008, 62, 125-132. [CrossRef] [PubMed]

42. Rivière, D.; Szczebara, F.M.; Berjeaud, J.-M.; Frère, J.; Héchard, Y. Development of a real-time PCR assay for quantification of Acanthamoeba trophozoites and cysts. J. Microbiol. Methods 2006, 64, 78-83. [CrossRef] [PubMed]

43. Shannon, K.E.; Lee, D.-Y.; Trevors, J.T.; Beaudette, L.A. Application of real-time quantitative PCR for the detection of selected bacterial pathogens during municipal wastewater treatment. Sci. Total Environ. 2007, 382, 121-129. [CrossRef] [PubMed]

44. Mull, B.J.; Narayanan, J.; Hill, V.R. Improved method for the detection and quantification of Naegleria fowleri in water and sediment using immunomagnetic separation and real-time PCR. J. Parasitol. Res. 2013, 2013, 608367. [CrossRef] [PubMed]

45. Lund, M.; Nordentoft, S.; Pedersen, K.; Madsen, M. Detection of Campylobacter spp. in chicken fecal samples by real-time PCR. J. Clin. Microbiol. 2004, 42, 5125-5132. [CrossRef] [PubMed]

46. National Oceanic and Atmospheric Administration (NOAA). National Centers for Environmental Information. Available online: https:/ / www.ncdc.noaa.gov/cdo-web/search (accessed on 1 November 2017).

47. Helsel, D.R. Statistics for Censored Environmental Data Using Minitab and R; John Wiley \& Sons: Hoboken, NJ, USA, 2011.

48. Ahmed, W.; Vieritz, A.; Goonetilleke, A.; Gardner, T. Health risk from the use of roof-harvested rainwater in Southeast Queensland, Australia, as potable or nonpotable water, determined using quantitative microbial risk assessment. Appl. Environ. Microbiol. 2010, 76, 7382-7391. [CrossRef] [PubMed]

49. Hamilton, K.A.; Ahmed, W.; Toze, S.; Haas, C.N. Human health risks for Legionella and Mycobacterium avium complex (MAC) from potable and non-potable uses of roof-harvested rainwater. Water Res. 2017, 119, 288-303. [CrossRef] [PubMed]

50. Fewtrell, L.; Kay, D. Quantitative microbial risk assessment with respect to Campylobacter spp. in toilets flushed with harvested rainwater. Water Environ. J. 2007, 21, 275-280. [CrossRef]

51. Haberland, M.; Bakacs, M.; Yergeau, S. An investigation of the water quality of rainwater harvesting systems. J. NACAA 2013, 6. Available online: https:/ /www.nacaa.com/journal/index.php?jid=205 (accessed on 16 January 2018).

52. Ahmed, W.; Gardner, T.; Toze, S. Microbiological quality of roof-harvested rainwater and health risks: A review. J. Environ. Qual. 2011, 40,13-21. [CrossRef] [PubMed]

53. Ahmed, W.; Huygens, F.; Goonetilleke, A.; Gardner, T. Real-time PCR detection of pathogenic microorganisms in roof-harvested rainwater in Southeast Queensland, Australia. Appl. Environ. Microbiol. 2008, 74, 5490-5496. [CrossRef] [PubMed]

54. Lye, D. Virulence characteristics of bacteria isolated from cistern water systems in rural northern Kentucky. In Proceedings of the Fourth International Conference on Rain Water Cistern Systems, Manila, Philippines, 2-4 August 1989.

55. Lye, D. Microbial water quality associated with rooftop rainwater harvesting-Implications for risk management. In Proceedings of the American Water Works Association Sustainable Water Management Conference and Exposition, Portland, OR, USA, 18-21 March 2012; pp. 424-437.

56. Lye, D.J. Bacterial levels in cistern water systems of northern Kentucky. J. Am. Water Res. Assoc. 1987, 23, 1063-1068. [CrossRef]

57. Diederen, B.M.W. Legionella spp. and Legionnaires' disease. J. Infect. 2008, 56, 1-12. [CrossRef] [PubMed] 
58. Murphy, H.M.; Meng, Z.; Henry, R.; Deletic, A.; Mccarthy, D. Current stormwater harvesting guidelines are inadequate for mitigating risk from Campylobacter during non-potable reuse activities. Environ. Sci. Technol. 2017, 51, 12498-12507. [CrossRef] [PubMed]

59. Brodribb, R.; Webster, P.; Farrel, D. Recurrent Campylobacter fetus subspecies bacteraemia in a febrile neutropaenicpatient linked to tank water. Commun. Dis. Intell. 1995, 19, 312-313.

60. Merritt, A.; Miles, R.; Bates, J. An outbreak of Campylobacter enteritis on an island resort, north Queensland. Commun. Dis. Intell. 1999, 23, 215-219. [PubMed]

61. Lu, J.; Struewing, I.; Yelton, S.; Ashbolt, N. Molecular survey of occurrence and quantity of Legionella spp., Mycobacterium spp., Pseudomonas aeruginosa and amoeba hosts in municipal drinking water storage tank sediments. J. Appl. Microbiol. 2015, 119, 278-288. [CrossRef] [PubMed]

62. Bonett, D.G.; Wright, T.A. Sample size requirements for estimating Pearson, Kendall and Spearman correlations. Psychometrika 2000, 65, 23-28. [CrossRef]

63. PWD. Green Infrastructure, on Philadelphia Water Department. 2012. Available online: http://www. phillywatersheds.org/what_were_doing/green_infrastructure (accessed on 31 October 2017).

64. Schoen, M.E.; Ashbolt, N.J.; Jahne, M.A.; Garland, J. Risk-based enteric pathogen reduction targets for non-potable and direct potable use of roof runoff, stormwater, and greywater. Microb. Risk Anal. 2017, 5, 32-43. [CrossRef]

65. Schoen, M.E.; Garland, J. Review of pathogen treatment reductions for onsite non-potable reuse of alternative source waters. Microb. Risk Anal. 2015, 5, 25-31. [CrossRef]

(C) 2018 by the authors. Licensee MDPI, Basel, Switzerland. This article is an open access article distributed under the terms and conditions of the Creative Commons Attribution (CC BY) license (http:/ / creativecommons.org/licenses/by/4.0/). 